\title{
Niche partitioning of microbial communities at an ancient vitrified hillfort: implications for vitrified radioactive waste disposal
}

\author{
A.E. Plymale ${ }^{1}$, C.I. PeArCE ${ }^{1 *}$, J.R. Wells ${ }^{1}$, C.J. \\ BRISLAWN $^{1}$, E.B. GRAHAM ${ }^{1}$, T.E. CHEEKE ${ }^{2}$, J.L. \\ ALLEN $^{3}$, V.G. DANNA ${ }^{1}$, J.L. WEAVER ${ }^{4}$, J.S. MCCLOY ${ }^{5}$, \\ R. SJÖBLOM ${ }^{6}$, E. HJÄRTHNER-HOLDAR ${ }^{7}$, M. ENGLUND ${ }^{7}$, \\ E. OGENHALL ${ }^{7}$, D.K. PEELER ${ }^{1}$ AND A.A. KRUGER ${ }^{8}$ \\ ${ }^{1}$ Pacific Northwest National Laboratory; ${ }^{2}$ Washington State \\ University (WSU), Richland, WA, 99354; ${ }^{3}$ Eastern \\ Washington University, Cheney, WA, 99004; ${ }^{4}$ National \\ Institute of Standards and Technology, Gaithersburg, \\ MD, 20899; ${ }^{5}$ WSU, Pullman, WA, 99164, USA; ${ }^{6}$ Luleå \\ University of Technology, Luleå; ${ }^{7}$ Arkeologerna, \\ Uppsala, Sweden; ${ }^{8}$ US Department of Energy, Office of \\ River Protection, Richland, WA 99354, USA. \\ (*correspondence: carolyn.pearce@pnnl.gov)
}

Because microbes cannot be eliminated from radioactive waste disposal facilities, the consequences of bio-colonization should be examined. At a pre-Viking era vitrified hillfort, Broborg, anthropogenic glass has been subjected to biocolonization for over 1,500 years. Broborg is used as a habitat analogue for disposed radioactive waste glass to inform how microbial processes might influence long-term glass durability. Scanning electron microscopy and DNA sequencing of material from the vitrified wall, adjacent soil, and general topsoil, show that the geochemical and mineralogical conditions on the ancient glass support a niche microbial community of bacteria, fungi, and protists involved in glass alteration. Communities associated with the vitrified niche are distinct and less diverse than soil communities, with the microbiome dominated by lichens, lichen-associated microbes, and other epilithic, endolithic, and epigeic organisms. These organisms exhibit bio-corrosive properties, including silicate dissolution, extraction of essential elements, and secretion of geochemically reactive organic acids, that could be detrimental to glass durability. However, long-term biofilms also possess a homeostatic function that could limit glass alteration. This study demonstrates potential impacts that microbial colonization and niche partitioning can have on glass alteration, and subsequent release of radionuclides from a disposal facility for vitrified radioactive waste. 